ut any one time. When mice are painted on the lanks with single applications of benzpyrene, the yield of tumours is affected by the condition of the sair at the time of painting, but because the spread of the new coat is very easily disturbed, for example, sy plucking the hair or even by clipping it, conrolled conditions are difficult to maintain. This conirms Haddow's finding that coat change is easily listurbed.

Mount Vernon Hospital,

J. C. Motriram.

Northwood, Middlesex. April 3.

' Nature, 155, 379 (1945).

\section{Synthesis of the Differential Growth Inhibitor, $\delta$-Hexenolactone}

Two years ago, Medawar, Robinson and Robinson ${ }^{x}$ described the isolation from a commercial malt extract of small quantities of a steam-volatile substance which inhibited the growth of fibroblasts and other mesenchyme cells at concentrations which permitted the free growth of epithelial tissue. It seemed probable that this material was an unsaturated lactone, $\mathrm{C}_{6} \mathrm{H}_{8} \mathrm{O}_{2}$, and it was found that synthetic specimens of $d l-\delta-\Delta \alpha \beta$-hexenolactone (III) (the $d$-form of which occurs in the fruit of the mountain ash) exhibited similar inhibitory properties, although the activity was rather less than that of the natural inhibitor. The differential growth-inhibitory properties of this lactone have since been confirmed by other workers ${ }^{2}$.

The $d l$-lactone (III) was synthesized in small yield by Medawar, Robinson and Robinson by condensation of acetaldol with malonic acid in pyridine solution, and Kuhn and Jerchel ${ }^{3}$ obtained it from $\beta: \delta$-dibromocaproic acid by boiling with water, the overall yield from sorbic acid being about 25 per cent. We have now found that the lactone can be prepared readily as follows :

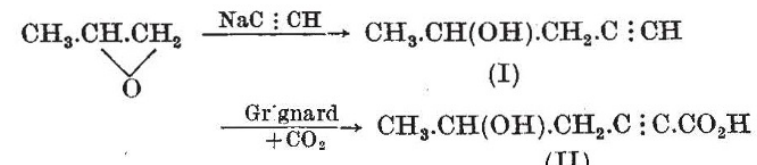<smiles>CCC(C)OC1CCCCC1</smiles>

Condensation of propylene oxide with sodium acetylide in liquid ammonia gives the carbinol (I) in 50 per cent yield. Treatment of the carbinol with two equivalents of ethylmagnesium bromide followed by carboxylation with carbon dioxide under pressure results in a 75 per cent yield of the crystalline hydroxyacetylenic acid (II), m.p. $59^{\circ}$, which on semihydrogenation employing a 0.3 per cent palladium - barium sulphate catalyst gives $d l-\delta-\Delta^{\alpha \beta}$-hexenolactone directly, as a colourless stable oil, the overall yield from propylene oxide being about 35 per cent. The constants of the lactone are in agreement with those recorded by Kuhn and Jerchel ${ }^{3}$, and it exhibits the expected growth-inhibitory action*.

* We are indebted to Sir Robert Robinson and Dr. Medawar for a report on the inhibitory properties.
This synthesis has the advantage of being readily adaptable to the preparation of related lactones, and these lines are being actively pursued.

I. J. HAYNes.

E. R. H. Jones.

Department of Organic Chemistry,

Imperial College,

London, S.W.7.

March 27.

${ }^{1}$ Nature, 151, 195 (1943).

${ }^{2}$ Kuhn, Jerche], Moewus, Moller and Lettre, Naturwiss., 31, 4t8 (1943) ; Hauschka, T. S., Nature, 154, 769 (1944).

${ }^{3}$ Ber. Chem. Ges., 76, 413 (1943).

\section{Metabolism of Quinine in Chick Livers}

Is a recent paper Oldham, Kelsey, Cantrell and Geiling ${ }^{1}$ reported that in White Leghorn chicks dosed with quinine the concentrations of alkaloid in the tissues were lower in young chicks than in grown birds. They suggested that quinine was metabolized more rapidly in chicks than in older birds. In vitro experiments by these workers on the quinine oxidase activity of the tissues, however, failed to show any activity in the liver, and showed only very slight activity in the kidney.

In similar experiments on quinine oxidase activity, we have been able consistently to demonstrate definite activity in chick livers (strain : Rhode Island Red $\times$ Light Sussex). Moreover, the activity decreased with increasing age, as shown in the accompanying table. Chick embryo livers and whole embryos show a very high activity.

\begin{tabular}{|c|c|}
\hline Material & $\begin{array}{l}\text { Mean quantity of quinine } \\
\text { (micrograms) metabol- } \\
\text { ized in } 2 \text { hours by } \\
0.5 \mathrm{gm} \text {. tissue }\end{array}$ \\
\hline 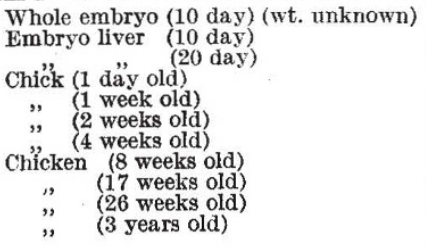 & $\begin{array}{r}70 \\
216 \\
154 \\
87 \\
97 \\
69 \\
94 \\
53 \\
45 \\
19 \\
26\end{array}$ \\
\hline
\end{tabular}

The discrepancy between our observations and those of Oldham et al. might be partly due to the fact that we used the phosphate buffered salt solution of Krebs and Henseleit ${ }^{2}$ instead of ordinary RingerLocke solution, and also raised the temperature of incubation to $40^{\circ} \mathrm{C}$. to correspond with the body tem. perature of the birds. In one experiment on the liver from a three-week old chick in Ringer-Locke, only 30 micrograms of quinine were metabolized. Other causes of the difference of results might be differences in the strain of birds used, or dietary variations. We have in some cases experienced large variations in the quinine oxidase activity among birds of similar age.

Wellcome Laboratories of Tropical Medicine,

$$
\text { P. B. Marshall. }
$$
183-193 Euston Road, London, N.W.1. April 11.

1 Oldham, F. K., Kelsey, F. E., Cantrell, W., and Geiling, E. M. K., J. Pharm. and Exp. Therap., 82, 349 (1944).

${ }^{2}$ Krebs, H. A., and Henseleit, K., Z. physiol. Chem., 210, 33 (1932). 